\title{
Economic Growth and Financial Instability: The Ideas of Hayek and Keynes
}

\author{
Noemi Levy Orlik
}

\author{
Full-Time Professor at UNAM, Faculty of Economics in Mexico, Mexico
}

\begin{abstract}
Complex monetary systems in capitalist economies, whose financial markets can cause financial instabilities and economic downturns is an accepted argument by both John M. Keynes and Friedrich A. Hayek, disagreeing in terms of the factors generating financial instability, the mechanism in which financial variables affect the real sector, and more importantly how to generate economic growth.

In this paper we discuss Hayek and the Austrian monetary school innovative ideas in terms of money in capitalist economies (i.e., liquidity provisions and credit devaluations) from where the monetarism and later the New Classical framework developed; and revise Keynes and Post Keynesian views that recognized the full effects of money in productions arguing that debts precede money, which is non neutral, thereby can expand economic activity but also unfold financial instability.
\end{abstract}

We concentrate in the dissenting views over financial instability and argue that the main way to overcome economic activity is through expansive fiscal policies, opposing wages cuts, along financial market regulation.

Keywords: Economic Theory, Financial Instability, Hayek and Keynes.

\section{INTRODUCTION}

The discussion between Hayek and Keynes took place in the light of the 1929 crisis, and unlike present times, was part of a vast and interesting analysis of the causes and remedies of economic crises, in which the Theory of Money underwent a deep scrutiny that revolutionized the understanding of money and of financial institution operations and their effect on the real side of economic activity. Friedrich A. Hayek was part of the Austro-German Monetary tradition that rejected government intervention in economic activity, while John Maynard Keynes was the founder of a new theoretical framework that put forward the idea of government intervention, with anti-cyclical fiscal and monetary policies

In the light of the discussion of the early years of the twenty century, the economic discipline divided in two major visions, (excluding the Marxian School). The school of Effective Demand founded by John Maynard Keynes evolved into the Post-Keynesian stream of thought put in the forefront of capitalist economies analysis highly complex monetary systems, in which financial variables provide liquidity to finance capital accumulation but also sets-off economic instability. The Austrian school The neoclassical stream of thought became highly critical of the existing mainstream school of thought (i.e., the Quantity Theory of Money -hereafter QTM) and sustained innovative ideas in

*Address correspondence to this author at the Facultad de Economia, UNAM, Edificio Principal, Circuito Interior S/N, Coyoacán, Cd. Universitaria, 04510 Ciudad de México, D.F.; Tel: (52)(55) 56221780; E-mail: levy@unam.mx terms of the monetary variables at work in capitalist economies, such as liquidity provisions and credit devaluations that later evolved in the New Classical framework. In addition they critical to government intervention in the economic activity, supporting the "Treasury View" that privileged wage cut policies to overcome recessions, not recognizing fully the effects of money on the real side of the economy.

Hayek distinctiveness was his rejection of the assumption that increased volumes of money in circulation (or, monetary interest rates departures from equilibrium positions) only modify the general price level of the economy, distancing himself from the "rudimentary theory of money" summed up in the QTM and the monetarist school of thought that evolved in later decades; ${ }^{1}$ but disagreed with government economic intervention policies, particularly under the form of monetary policy (modifying the monetary rate of interest) since it "can make things worse", i.e., induce overinvestment, that will retrieve economic activity to previous stages of development.

In the light of Keynes and Hayek arguments, the notions of one general equilibrium position and the static economic system are rejected. Both authors analyze capitalist economies on the basis of dynamic systems because of the constant changes that take

\footnotetext{
${ }^{1}$ Kaldor 1970:3 differentiated Hayek and Von Misses from Monetarists (Friedman) for being more liberally spiced with 'the new empiricism, and more importantly Friedman missed some of the subtleties of the Hayekian transmission mechanism, and of the money-induced distortions in the "structure of production".
} 
place in the organization of the factors of production. The disagreement between Hayek and Keynes lie on the ways economy evolves: Hayek assumes that the economic system operates under full employment and higher levels of production are reached through forced savings that takes place by increasing the labor division of production, which are new ways of organizing the production factors based on relative price divergence to achieve higher stages of production. Keynes claim that Hayek transmission mechanisms does not operate within complex monetary economies, based on credits and debts, since the capitalist productive organization is structurally unable to operate under full employment conditions because there is no guarantee that enterprises spending re-circulates back to the economy. Therefore Keynes, unlike Hayek, favors government economic policies to counteract the reduction of private spending (i.e., demand). Initially, he proposed active monetary policies that would reduce long-term rates of interests for investment spending not to fall, replaced after the 1929 economic crash by direct public spending in investment activities, along with financial regulation to limit financial gains.

The result of the discussion between Keynes and Hayek led to two important issues: the understanding of the capital market operations and the relevance of government policies. Keynes argued that there was a relation between underinvestment and price divergence that would not be solved by market operations, whereby central bank intervention is required to control long rate of interest. Later, on the basis of uncertainty that dominates capital market speculation, he claimed that underinvestment requires economic policies in the way of guaranteeing "social investment" along with the euthanasia of rentiers, the later attained through restricting capital market operations. Minsky (1964, $1975,1986)$ modified the heterodox views on financial activity, arguing that capital market need to provide liquidity not only for financing investment and production but for the functioning of the whole capitalist system. Our conclusion is that the main problem of underinvestment is related to high concentration of income, reduced investment returns, facilitated by capital market operations, which need to be regulated so that they concentrate in providing long term provide final finance.

This paper is divided 4 sections. The first section is devoted to Hayek notions of capitalist production organization and monetary economic cycles, followed by a second section where Keynes' views on capitalist monetary system are developed, specifically on the rate of interest (rejecting the natural rate) and the impact of uncertainty on the workings of the capital market, from where follows his idea on rigid prices and underinvestment. The third section is devoted to modern theories of capital markets, and lastly the conclusions are put forward.

\section{HAYEK' VIEWS ON ECONOMIC GROWTH, ECONOMIC CYCLES AND MONEY VARIABLES}

Hayek' discussion on how the economy operates can be found in two important books written at the end of the 1920. Prices and Production and Monetary Theory and the Trade Cycle that shed light on how price mechanisms operates in dynamic capitalist productive organizations, and on the relation between monetary policy and economic cycles.

\section{Prices and Production: Relative Price Changes and the Mobilization of Resources between Consumption and Investment to Expand Final Goods}

Hayek starts analysing the nature and causes of the changes of industrial output, under the assumption that all available resources are employed. This statement is based on methodological rather empirical considerations because is assumed that production expands if unused resources are put into operation. In this respect, he claims that is important to understand why industrial output expands, which he relates "to the willingness of individuals to expand effort" (1931:32).

A second important element is that production expands if the utilization of existing resources is reorganized. This is achieved through lengthening the process of production, which means adding more stages of intermediate products. He writes:

"(this is) made possible by a transition to more capitalistic method of production ... (in that way) the available resources are employed for the satisfaction of the needs of a future more distant than before" (1931:36, parenthesis ours). The attainment of a more capitalist mode of production generates "a greater quantity of consumers' goods out of a given quantity of original means of production ${ }^{2 \prime}$. (1931: 37-38)

\footnotetext{
${ }^{2}$ Hayek defines means of production as land and labor (1931:36)
} 
In this context, is assumed that capitalist economies use money to cover the needs of production, which requires the reorganization of existing factors of production that modifies the proportions in consumer and intermediate goods (1931:46) as the economy turns more capitalist. This process is set off by changes in relative prices, namely the price obtained for the product on a particular stage of production and the price paid for the intermediate products taken from the preceding stages of production. The starting point occurs when 'the total demand for producers' goods (expressed in money) increases relatively to the demand for consumer demand" (1931:50). This process can be achieved through voluntary savings defined as "simple shifts of demand between consumers' goods and producers goods" (ibid) or involuntary savings, which is "a change in the quantity of money which alters the funds at the disposal of the entrepreneurs for the purchase of producers' goods" (lbid).

The first way to reach higher state of capitalist production is based on the assumption that savings are spent in the same period (forced savings), consequently agents' decision of reducing consumption (i.e., savings) expands the number of stages of intermediate production that will result in higher volumes of goods and services at the end of the process. In terms of relative price divergence, consumption prices will fall more than production prices during the course of the economic cycle. In Hayek words: "the price of a unit of the factors of production of which (if we neglect the increase of capital) has remained the same, will fall in the same proportions, and the price unit of consumers' goods, the output which has increased as a consequence of more capitalists method of production, will fall in still greater proportions" (1931:53). Accordingly "The amount of money spent in each of the later stages of production has also decreased, while the amount of money used in the earlier stages has increased, and the total spent on intermediate products has increased also because of the addition of a new stage of production" (1931:53). From where he concludes:

"When a change in the structure of production was brought about by savings we are justified in assuming that the changed distribution of demand betweens consumers' goods and producers' goods would remain permanent ... Only because a number of individual has decided to spend a smaller share of their total income receipts on consumption and a large share on production was there any change in the structure of production", (1931:55-57)

If this process comes through with bank credits, the volume of money in circulation will not adjust throughout the different phases of production to the new proportions consumer and producers' goods (i.e., involuntary savings), prices of consumers' goods rise, and will be felt by those who will not get the benefits of higher returns. Therefore if there is no retrenchment of consumption by those who will reap the benefits from by the new investment, it will bear upon "consumer(s) in general who, because of the increased competition from the entrepreneurs who have received the additional money, are forced to forego part of what they have used to consume" (1931:57, our parenthesis) and they get "less goods for their money incomes" (1931:57). From where Hayek concludes that if money continues to increase, consumption will also be expanded on the basis of an artificial distribution of income, consumers' prices increases and the new structure of production will move back to the old proportions. Consequently, some of the new capital sunk in equipment adapted to the more capitalist processes will be lost. The key point in this discussion is the new money volume in circulation (amplifies liquidity channelled to the productive sector) prevents changing the "proportion between the demand for consumers' goods and the demand for intermediate products" (1931:58)

Interest rates are introduced to account for the risk of lengthening the production process; therefore interests are a result of price margins between consumers' and productions' goods, i.e., when money receipts exceeds total costs, which according to Hayek are for those who "risk more money by investing it in production rather than let it remain idle" (1931:74). In this context, investment is rewarded with interests due to the risks it entails; and is assumed "that margins get smaller as the production process comes to an end" (1931:74). In a state of equilibrium the amounts paid in interest coincide with the price margins, and since the prices of production goods rise at decreasing rates, investments spending in the final stages of production will be halted, and consumers' goods demand, whose prices have reduced, will increase.

Consequently, if central bank expands money (i.e., involuntary savings) loan interest rates go down, new credits are available and new stages of production of intermediate goods are added, not reducing the 
demand of consumption goods. A scarcity of consumer goods will take place, and their price will go up, which will "mean a new and reversed change of the proportion between the demand for consumers' goods and demand for producers' goods in favour of the former" (1931: 89)

\section{Monetary Theory and the Trade Cycle: Overinvestment and Crisis}

In this book is argued that monetary policy can't overcome recession. In Hayek words: "To combat the depression by a forced credit expansion is to attempt to cure the evil by the very means brought it about" (1933:21). Hayek' main point is that monetary analysis has oversimplified the effects of money on production "which results from reducing all cyclical fluctuations to fluctuations in the value of money" (1933:47).

Based on the idea that economic cycles are related to disproportionalities because of excessive production of capital goods increases more than the corresponding flow of consumption, a scarcity of finished consumption goods develops, the price of these goods go up (which amounts to the same thing as a rise in the rate of interest), "so that it becomes unprofitable to employ the enlarged productive apparatus or, in many cases, even to complete it". (1933:56). Hayek argues that in barter economies credits, available at unchanged prices, cannot unfold disproportions since the rate of interest "keep the extension of the productive apparatus within economically permissible limits" (1933:87). In his words:

"absence of money, interest would effectively prevent any excessive extension of the production of production goods, by keeping it within the limits of the available supply of savings, and that an extension of the stock of capital goods which is based on a voluntary postponement of consumers' demand into the future can never lead to disproportionate extensions, then it must also necessarily be admitted that disproportional developments in the production of capital goods can arise only from the independence of the supply of free money capital form the accumulation of savings" (1933:92).

The discussion of economic cycles in sophisticated money economies is based on the ideas that changes in the volume of money will give way to a new state of the economy; rejecting the circularity and "closedeness" assumptions of the QTM (higher level of money in circulation necessary provokes a higher level of prices in the economy). Hayek, on the basis of Wicksell-Misses analysis ${ }^{3}$ notes that an expanding economy simultaneously cannot attain price-level stability and equality between monetary and natural rate of interest. Specifically the former requires higher levels of money in circulation, but at the same time it will cause discrepancy between the monetary and natural rate of interest, and more importantly it can "lead to a distribution of productive resources between capital-goods and consumption-goods which differs from the equilibrium distribution", (1933:119). From the preceding argument Hayek derives that "the point of real interest to Trade Cycles Theory is the existence of certain deviations in individual price-relations occurring because changes in the volume of money appear at certain individual points, deviation, that is, away from the position which is necessary to maintain the whole system in equilibrium". (1933:123)

Under these conditions, the effects of the deviation between the natural and the monetary rate of interest is due to the periodically recurrence of disproportions in the structure production. The peculiarity of Hayek's analysis is that the natural rate of interest moves due to endogenous factors of the economy (not as a result of a policy decisions), that "recurs under the existing organization" (1933:148). In this discussion surfaces an extremely revolutionary idea for the neoclassical school (shared with Keynes) that credit issuance through deposits are not related to savings, thereby the capitalistic system (or the existing credit organization in Hayek terms) inevitable undergoes monetary fluctuations. The argument can be summarized as follows:

"since the rate of interest charged by banks to their borrowers is not promptly adjusted to all changes in the economic data -either because the supply of bank credits is, within certain limits, fundamentally independent of changes in the supply of savings, or because the banks have no particular interest in keeping the supply of bank credit in equilibrium with the supply of savings and because it is, in any case impossible for

${ }^{3}$ Hayek argues that Wicksell and Misses ideas on trade cycles can be traced to Thornton, Ricardo, Macleod; Sigwick, Giffen, Nicholson and Marshall (1933:109-110) 
them to do so ... then monetary fluctuation must be inevitable" (1933:151-152), on the basis of which Hayek derives that "banks create money credit 'as they please" (1933: 165), moreover bank credits "does not depend on the bank but on the demands made by commerce and industry how far banks expand credit" (1933: 166).

Hayek argues that bank will meet credit on the assumption that natural rates has increased, which means that, a given amount of money, can now find more profitable employment than hitherto without increasing the rate of interest due to competitive reasons (single banks confront the increase in demand thereby they will not raise the rate of interest). Even more, he claims that in the "upward phase of the cycle, the risks of borrowing are less, and therefore a smaller cash reserve may suffice to provide the same degree of security", (1933: 173).

The effects of raising credits (when boom proceeds) also can be interpreted as lowering interest rate that pull down capital goods prices and only subsequently those of consumption goods leading to well know consumption shortage, leading to what has been characterizes as a crisis, since new investment productions will not be realized. However, what is important in this discussion that once bank realize the limitations "the money rate must, despite the increased total volume in circulation, rise again to its natural level and render unprofitability (temporarily at least) those investment which were created with the aid of additional credit", (1933: 173).

In this context Hayek is against monetary policy reducing the rate of interest or increasing the volume of money in circulation even in recession periods. According to him, economic cycles can only be avoided by controlling the expansion of credits and making the monetary rate interest to coincide with the natural rate of interest (Caldwell, p. 19). And once recession breaks out the best policy would be to allow things to work by themselves: any attempt to stimulate the economy by further injections of money would keep artificially low the monetary rate of interest and disturb even more the structure of production and thereby prolong the crisis (ibid).

\section{KEYNES VIEWS ON MONEY, CREDIT AND FINANCIAL MARKET}

The characterization of money put forward by Keynes differs from his fellow economist. He assumes that only banks can issue credits ex-nihilo (i.e., through monetary claims against themselves), all economic variables are expressed in monetary terms including returns and, more importantly, money is non-neutral, thereby can set off economic cycles. This argument is summarized in a short paper named "A Monetary theory of production" (1933), where he argues:

"it is my belief that the far-reaching and in some respects fundamental differences between the conclusions of a monetary economy and those of the more simplified real-exchange economy have been greatly underestimated by the exponents of the traditional economics; with the result that the machinery of thought with which realexchange economics ... (that) has led in practice to many erroneous conclusions and policies. The idea that it is comparatively easy to adapt the hypothetical conclusions of a real wage economics to the real world of monetary economics is a mistake".

On the basis of a monetary theory of production he put forward a different economic framework, in which investment spending is the more dynamic variable of production, and its variability set offs economic cycles. Unlike Hayek, he assumes that consumption is a constant portion of income that does not induce booms or recessions, thereby economic downturns are related to underinvestment rather than overinvestment spending, and insufficient demand cannot be reversed by market mechanisms. The trade-off argument between consumption and investment is dismissed, the loanable fund theory is rejected, and consumption needn't fall to free productive resources to expand investment. A mayor finding of Keynes that differentiates him from Hayek is that capitalist economies cannot structurally operate under conditions of full employment. In this context money, credit and interest rates have a different role in the determination of production and employment. Instead of limiting the realization of increasing investment, it can set off of investment, income and employment, so long as credit advances are channelled to the production sector.

\section{"A Treatise on Money": Central Bank Control of the Rate of Interest to Neutralize Underinvestment}

In this book, Keynes follows the chartalist view, in which money is a symbol, backed by a center power that enforces the recognition of debts and the means of 
their discharge. (1930a:4). Bank money circulates alongside the state money, defined as the "acknowledgment of a private debt, expressed in the money-of-account, which is used by passing from one hand to another, alternatively with Money-Proper, to settle a transaction" (1930a:6). This form of money is converted into representative-money that forms currency money, where are included all type of money, including banks deposits.

A central argument is that advances are created through banks' monetary claims against themselves, i.e., deposits, which that take different forms. Keynes writes:

"It may itself purchase assets, i.e., adds to
its investments, and pay for them, in the
first instance at least, by establishing a
claim against itself. Or the bank may
create a claim against itself in favor of a
borrower, in return for his promise of
subsequent reimbursement; i.e., it may
make loans or advances" (1930a: 24$)$.

The relevant issue is that banks' deposits are either an exchange for values received (agents usual deposit related to savings) or against future promises (loans), and their cancellation takes place once claims against them are exercised in cash or transferred to other banks (1930a: 24). Moreover, he describes the possibility of a pure credit system: ${ }^{4}$

"If we suppose a closed banking system ... in a country where all payments are made by cheques and no cash is used, and if we assume further that the banks do not find it necessary in such circumstances to hold any cash reserves but settle inter-bank indebtedness by the transfer of other assets, it is evident that there is no limit to the amount of bankmoney which the banks can safely create provided that they move forward in step. The words italicised are the clue to the behavior of the system" (1930a, p. 26).

In Keynes discussion, the rate of interest and its relation with investment spending holds a key position

\footnotetext{
${ }^{4}$ This discussion put forward by Le-Bourva, 1992, Graziani, 2003, further developed by the Circuitists (Moore, 1989, Bellofiore and Seccareccia, 1999, Parguez and Seccareccia (2000) and Rochon 1999, 2006, among others ) that centered their argument on bank credit provision at constant rate of interest as a necessary condition (but not sufficient) for capital accumulation to expand and set off economic growth.
}

in explaining economic cycles, being the long term (bond) rate the leading rate and not the bank rate (short rate of interest); ${ }^{5}$ highlighting that both rate of interests has important interconnections, therefore central bank can modify the bond rate through varying the bank rate and through direct acquisitions of bonds. In this context, the bond rate can be shaped by monetary policies.

In the discussion of controlling the rate of interest, ${ }^{6}$ Keynes acknowledges that the banking system needs to provide resources for the production and circulation of production (including the working capital) and also for stabilizing financial price instruments. Second, the yield curve is considered to be relatively constant, and its slope move up and down along its whole length in response to changes in the money market rate of interest, which is the discount rate. He writes:

"it is broadly true to say that the governor of the whole system is the rate of discount. For this is the only factor which is directly subject to the will and fiat of the central authority, so that it is from this that induced changes in all other factors must flow" (1930b: 211); and adds "experience shows that, as a rule, the influence of the short-term rate of interest on the longterm rate is much greater than anyone who argued on the above lines would expected. We shall find, moreover, that there are some sound reasons, based on the technical character of the market, why it is not unnatural that this should be so" (1930b: 353).

This process operates through arbitrage between banks and financial institutions that modify the composition of their portfolios towards bonds if the money market rate became too low. There are different ways in which low interest rates (cheap money) can affect credit costs and securities' returns (1930b: 356362 ). If the running yield on bonds is greater than the rate payable on short-term loans, it will be profitable to borrow short to buy long-term securities. Alternatively, if short-term yields are low, financial institutions will hasten to move into long dated securities, increasing

\footnotetext{
${ }^{5}$ Kalecki on similar basis argues that long term interest determines investment spending however this variable is explicitly omitted because its movement is resemble $d$ in the changes of the rate of profits.

${ }^{6}$ See Keynes, 1930b: Problems of National management-III. The control of the rate of interest of the, chapter 37 .
} 
their prices. Finally, and most strikingly, the rate of discount affects even 'professional investors' expectations, who have no intentions of holding securities long enough for the influence of distant events to have its effects. This takes place by lowering the "cost of borrowing and still more by their expectations on the basis of past experience of the trend of mob psychology ... the apparent certainties of the short period, however deceptive we may suspect them to be, are much more attractive" (1930b:361).

The alternative way to affect the rate of bonds is through central banks' direct acquisition of securities, till the long-term rate of interest would have reduced enough to stimulate new investments. Keynes writes: "the direction of the supply of resources which determines the value of securities through investments which it purchases directly and the loans which it makes to the Stock Exchange and to other persons who are prepared to carry securities with borrowed bank-money, and of the supply pari passu of the savings deposits required for the use in the Financial Circulation" (1930b:347).

In this period Keynes argued that these practices are very effective because only a small proportion of outstanding stock would be turned over in the secondary market where the yield for securities is determined; and in case central banks supply banks with more funds than required for the lending process, the short-term rate of interest will decline towards zero and, in a second moment, member banks would second the efforts of the Central Bank by themselves buying securities. Therefore, the problem of direct central banks acquisition of securities is that the price would be above "what it considers to the long-period norm" so that, "when in due course they have to be reversed by sales at a later date, (they) may show a serious financial loss" (Keynes 1930, cited in Toporowski, 2014); moreover: "this contingency ... can only arise as the result of inaccurate forecasting by the capitalist public and of a difference of opinion between the Central Bank and long-term borrowers as to the prospective rate of returns" 1930b:373 (for further discussion see Toporowski, 2014, chapter 6)

Summing up, Keynes unlike Hayek, starts of his analysis assuming that underinvestment explain economic cycles because of high bonds rates (above future expected real returns or marginal efficiency of capital); and capital markets determine the long term rate of interest that affects investment spending, therefore government intervention can stabilize (or destabilize) economic growth. In this context central bank direct intervention through credit provision or changes in short term rates of interest can smooth financial circulation. However, the events following the 1929 Great Crash showed that the reduction of the rate of interest did not produce what Keynes expected to happen in his "Treatise on Money". The reduction interest rates did not set off economic activity.

General Theory of Employment, Interest, and Money (GT): Uncertainty, Underinvestment and Direct Government Spending in Economic Activity

In this book money is considered as a special commodity. This argument is based, first, in that money has no value, from where is stated that it has a zero (or negligible) elasticity both of production and of substitution, it has total liquidity (equal to one), and negligible net returns (quasi-rents minus costs). Second, and derived from its special characteristics, its price is rigid downwards. In addition the long term rate is unable to balance savings and investment and market mechanism cannot solve between these two variables; from where he argues that income (instead of prices) is the accommodating variable. Third, in capitalist economies real savings can be hoarded; which according to Keynes, will take money out of circulation, reduce effective demand (and investment) and create unemployment. In Keynes' words:

"The first condition means that demand may be predominantly directed to money, the second that when this occurs labor cannot be employed in producing more money, and the third that there is no mitigation at any point through the same factors being capable, if it is sufficiently cheap, of doing money's duty equally well ... Thus a rise in money-rate of interest retards the output of all the objects of which the production is elastic without being capable of stimulating output of money" (1936:234).

On the basis of the previous arguments Keynes introduces uncertainty as an explanation of unemployment. He states: "Unemployment develops, because people want the moon; -men cannot be employed when the object of the desire (i.e., money) is something which cannot be produced and the demand for which cannot be readily choked off. There is no other remedy but to persuade the public that green cheese is practically the same thing and to have a 
green cheese factory (i.e., a central bank) under public control"(1936:235); from where he concludes that production factors are structurally under-employed in capitalist monetary systems, dismissing Hayek arguments of full employment.

Keynes argument on capital market operations has double edge effects. It is considered a space in which money accrues more money, setting the basis of financial gains and income concentration in the hands of rentiers in one side, and is a long term source of finance, that Keynes named funding ${ }^{7}$ (or final finance, see Bellofiore and Seccareccia, 1999). The concept that money accrues money, or what Marx labeled as interest bearing capital, is introduced in a rather peculiar way: the speculative demand of money, determined by psychological factors that destabilize investment and more importantly annuls monetary policy mechanism to counteract the fall of accumulation: the "objective of securing profit from knowing better than the market what the future will bring forth" (1936:108, chapter 13, II) produces highly volatile expectations, that unable monetary policies to control the rate of interest: "the long term rate may be more recalcitrant when once it has fallen to a level which on the basis of past experience and present expectations of future monetary policy is considered to be 'unsafe' by representative opinion" (1936: 202-203).

The long term fund provision of capital markets is based on the assumption that investment produces its own savings, and requires banks advances (short term liquidity), which will be cancelled through long term liquidity provisions that are matched with the creation of savings (i.e., bonds and shares sales). Alternatively investment is financed through retain profits (Kalecki 1939/1954) in which case shares and bonds are issued to equilibrate corporations' balance sheets, i.e., provide liquidity to illiquid (capital) assets.

In the $G T$, Keynes stresses the issue of uncertainty in capital market operations that induces economic cycles due to instable prices of bonds and share. In chapter 12, of the $G T$, Keynes argues that in capital markets unknown future can induce economic upturns, downturns, and more importantly recessions that are explained in the light of agents changing perceptions on the expected rate of interests. If future rates of interest are expected to rise, bond and share prices are

\footnotetext{
${ }^{7}$ This discussion is develop further in two papers in $1937(a, b)$ after publishing The General Theory.
}

expected to fall, savings are hoarded, and banks advances are not cancelled (although higher savings have increased); corporations balance sheets equilibrium can't be reached, and investment spending is reduced. In other words funding has not taken place or final finance cannot cancel initial finance, and economic cycles are disrupted.

In this discussion, the concept of natural interests rate is discarded, and the long term rate is defined as the "price which equilibrates the desire to hold wealth in the form of cash with the available quantity of cash" (1936:166-167); therefore the long-term rate of interest modifies the composition of savings (or ex-post investment) because it either can be hold in financial assets (and cancel previous debts, financial finance) or in money (hoarding). The latter destabilize the process of investment since short term debts (banks credits) or investment ex-ante (investment decisions) is not settled.

In this way is dismissed the concept of marginal productivity of capital, because the value of capital can change independently of its physical productivity as the desire (profitability) of its use modifies relative to its availability, from where it follows that the value of capital goods is determined by its "scarcity. ${ }^{8}$ More precisely, the relation between investment decisions and speculation is explained by investment prices of demand and supply, the former determined in the capital market (chapter XI, GT), in which future prospective yields in present values (discounted by the long-term rate of interest) are equal to the reposition price of capital assets (is the supply price determined in the real sector).

The reasons that bond and investment prices are 'incorrect' are discussed in detail in chapter XII of the $G T$, where Keynes highlights that the main source of instability lie in the future prospective yields due to the fundamental uncertainty on the future. In Keynes words:

"It would be foolish, in forming our expectations, to attach great weight to matters which are very uncertain ... it is reasonable to be guided to a considerable degree by the factors about which we feel somewhat confident, even though they may be less decisively relevant to the

\footnotetext{
${ }^{8}$ I owe this clarification to Tracy Mott.
} 
issue than other facts about which our knowledge is vague and scanty" (1936. p. 143). ... (He adds) "The element of real knowledge in the valuation of investment by those who own them or contemplate purchasing them has seriously declined" (1936, p. 154).

Keynes main argument of the key distortion of the valuations of investment prices is explained in terms of the intervention of expert professionals that, instead of possessing judgment and knowledge beyond that of the average private investors that would correct the vagaries of ignorant individuals, use their energies to speculate. In his words:

"The speculator or expert professionals are "largely concerned, not with making superior long-term forecast of the probable yield of an investment over its whole life, but with foreseeing changes in the conventional basis of valuation a short time ahead of the general public. They are concerned ... with what makes the market will value it at, under the influence of mass psychology, three months or a year hence" (1936. 154-155).

From the above is inferred that deep and broad capital markets can be detrimental for economic growth, especially in periods of high capital mobility since long-term irrevocable macroeconomic decisions (investment) can be turned into revocable individual decisions. Therefore, according to Keynes, uncertainty is one of the main features of investment valuation, especially when 'professional' investors (instead of 'entrepreneurs') dominate capital markets decisionmaking. ${ }^{9}$ On the basis of that considerations Keynes modified his economic policy propositions putting forward the need for government intervention to guarantee an amount of capital accumulation that would secure full employment and argued for reducing financial gains. His arguments for social investment and the euthanasia of rentiers ought to be understood on the light of the 1929 economic crash that unleashed the (First) Great Recession.

Therefore, Keynes limits government intervention through monetary policy, and more importantly that

\footnotetext{
'In light of the 1930's financial crisis, Keynes put forward the idea of introducing a substantial government transfer tax on all transactions, with a view to
} mitigating the predominance of speculation over investment in enterprise. capital market can roll over debts or provide funding for investment decisions, and even though he acknowledges that idle capitalist (financers) can appropriate higher shares of returns in the financial circuit and modify the concentration of income, the full effects of capital market operations on lengthening capital payments are not spelled out completely and is argued that capital markets with complex financial institutions operate differently of what Keynes spelled out in the GT. Thereby, thereby final finance or funding process are not spelled out completely

\section{NEW DEVELOPMENTS OF CAPITAL MARKET FUNCTIONING: FINANCIAL CIRCULATION, WEALTH CONCENTRATION AND BUSINESS CYCLES}

The above discussion highlights two important issues. The first one is related to the role of capital markets in providing liquidity for economic activity through controlling short rates of interest (Keynes 1930) and providing funding mechanism (Keynes, 1936 and 1937a,b), which can lead to financial gains (Keynes, 1936). The second issue is related to enforcing government direct spending in capital accumulation ("social" investment), which through the income multiplier amplify effective demand, increase profits, private investment and set off economic growth and employment. This proposition is followed by the propositions of rentiers' euthanasia, (Keynes, 1936).

Referring to the first proposition, ${ }^{10}$ we argue that capital market can expand corporations (financial and non-financial) balance sheets and modify governments financial assets and liabilities that can be associated (or not) to production decisions on one hand; and capital markets can lengthen short term debts, creating long term debts, that would equate corporations balance sheet, through providing liquidity to illiquid assets.

The capital market assessment are of importance and even though Keynes conclusions on capital market instability still have wide support, it is not clear whether his understanding of capital market operations withholds in modern capitalist economies with complex financial sectors. Minsky (1991) writes:

"Keynes wrote about capitalism. A generic capitalist economy is one in which private

\footnotetext{
${ }^{10}$ In this paper it is not discussed further government fiscal policies, since we concentrate in capital market operations.
} 
ownership of the means of production results in income to owners that in each case depends upon how a particular set of capital assets, organized in firms, performs in some market. The particular capitalist economy that ruled in Keynes' time was a small government economy with a sophisticated and evolving financial structure that had Central banks that were reluctant to intervene. Today's American and other rich capitalist economies are big government with even more sophisticated evolution prone financial structure" (Minsky, 1991:210)

Minsky' discussion on financial sector activity is based on balance sheet structures, "in which ultimate units combine its evaluation of the situation (the subjected impression of the chances of favorable and unfavorable outcomes), its own attitude towards uncertainty and the price of which will acquire the protection against unfavorable outcomes" (Minsky, 1964:186). This view moves away from agents expectations of future interest rates that determine the distribution of savings between financial instruments and hoarding to complex financial and non-financial institutions, which have dominated the last forty years of capitalist development.

The first issue to note is that financial complexity modifies corporations' balance sheet, particularly of the non-financial sector as well as of governments and central banks. In the case of non-financial corporations, assets are not only composed by investment decisions but also, and very importantly, by financial assets above of investment financial needs. The volume of financial assets and liabilities rise, the overall size of balance sheets expands, which leads to a diversification of financial sheet operations. According to Minsky, financial transactions can take place for "endorsing of other liabilities, the emission of their own liabilities in order to finance a position in others liabilities and pure "brokerage" activities" (ibid, 1964:187), distinguishing three types of balance sheets. First, "balance sheet account" that consist of payments related to existing liabilities or from existing assets that includes contractual dated payments of interest, rents and payments of dividends; Second, the "income account" which is money exchanged for final goods and services, not included unfinished goods; and most importantly, thirdly "portfolio payments" that exchanges money of either existing assets and newly- created assets, whose flow of account depicts the evolution of money in circulation and portfolio balances.

The "portfolio payments" stands out for generating liquidity through "near monies" than can either lengthen the debt structure of corporations that can be related (or not) to production activity or debts are issued to appropriate financial gains. In other words, increased financial activities are endogenous operations to stabilize corporations' balance sheet structures, or as exogenous factors that set off more debts, independently of real sector activities and, more importantly, dominate real sector decisions,. This can be summarized as a process of money that acquires more money, also described through "positions" defined as "those assets in portfolios or in balance sheets which cannot be converted readily into cash and the 'position-making assets' are the instruments used to acquire the cash needed to finance the buying of positions", Bellofiore and Ferri, 2001:3. These authors argue that "Each economic unit is a money-in-moneyout device: it must estimate the monetary receipts from its assets, deduct the financial commitments of holding positions, and assess their liquidity, (ibid: 6). In profit maximizing corporation, financial positions are accounted for exiting contractual debts that would cover payments of working capital and more importantly near moneys that would extend the term structure of debts.

The historical account for increasing debts in economic activity go back to the nineteen century (Company Acts), which set off private long term bond issuance, whose objective was the provision of long term finance for industrial activities (Keynes named this process as funding) and a means of acquiring financial gains, bringing into the forefront oligopolistic capitalist mode of production, (Michell and Toporowski, 20132014). Its most important outcome is that differentiated enterprises access to financial flows and financial gains, creates new financial circuits and surplus value appropriation, within economies and especially between countries (Lenin, 1916).

The question that remains to be answered is whether the process of increasing liquidity that took place after the demise of the Bretton Woods System that demonetized gold and enabled money to appear in its simplest form (debt) modified the structure of capitalism or led to a new mode of production in which financial capital dominated the entire economic system, reappearing the pre 1929 era. 
On the above account, we argue that from the 1980 s, on the basis of long term financial operations developed a deep process of market finance, based on financial innovations.; adding layers to financial intermediation, in which debt commitment cancelations depended on continuous raises of financial price instruments (financial inflation theory, see Toporowski, 2000). Specifically, productive capital was able to secure a financial counterpart in long term securities or liabilities of industrial or commercial assets creating many levels of financial circuits. The main argument is that one financial transaction doesn't cause one-off adjustment but a give rise to complex additional transactions. Referring to Companies Act, that transformed the financial system, Michell and Toporowski writes:

"Those securities were assets for their owner, had values, and could be traded in financial markets. ... they could be issue as collaterals (or securities, hence the term of securities) against bank loans. Such bank loans or credit created a second layer of financial intermediation on the underlying "real" assets. In its turn, bank credit may be used as security for further loans, adding a third and possible a fourth level of intermediation" (Michell and Toporowski, 2013-2014: 71).

This mechanism come along with active monetary policy (low rates of interests) and hedging activities that gave way to increase financial transactions. The former was a result of changes in interest rates or central bank operations, and the latter took place as a result of precautionary demand that developed the futures market (made possible to hedge commitments in the futures market or forward contract), increasing the possibilities for profitable hedging if the cost of the hedge contracts is less than the revenue from the commitments that is hedging (lbid). This author concludes that such innovations can be "functional in providing liquidity against a wider range of assets" (ibid:71)

The alternative view is that finance provided bank expands payments to production factors (salaries and profits) and also increases production. On that basis is argued that bank credit to solvents borrowers creates a process of debt creation and destruction that needn't destabilize economic activity, so long as central banks don't change the rate of interest, (Rochon, 2006). In this context, capital market activity is not required to produce long-term finance, and idle capitalist (or money capitalist) get hold of surplus produced by functioning capitalist that diminishes their returns, unless worker's salaries diminishes, creating a process of income concentration that favours the capitalist class. This leads to process of capital centralization.

In this context can be argued capital market long term finance can provide liquidity to illiquid assets and generate final finance so long as the rate of interests remains as an instrument of monetary policy that can shape this monetary decisions, highlighting that deficit fiscal policy (government direct economic spending above public income) is absolutely essential to overcome to economic recessions, especially in investment whose multiplier effect is higher, generating employment with no (or reduced) inflationary pressures. In this context, capitalist groups would rely more on investment activities rather than financial trade to operate their institutions. Therefore, there is scope of capital market to be functional in economic activities, especially for government long term finance to expand investment spending with reduced opposition of the capitalist class.

\section{CONCLUDING REMARKS}

In the light of the discussion between Hayek and Keynes can be argued that capitalist economies characterizes for being dynamic systems. Hayek arguments were crucial in mainstream though, for dismissing the theory of a unique general equilibrium since the rearrangements of the existing production factors can expand production. He also dismissed the QTM on the basis of that money is trapped in illiquid (real) assets and price need not be modified; however money is considered as neutral and capitalist economies are supposed to operate at full employment levels. There was no scope for anti-cyclical policy, since it would induce overinvestment that would retract capitalism to previous stages, because investments processes would not be completed; the revolutionary part being that price differentials were the driving force to add more stages of production.

Keynes extended further the argument. On the basis of price differentials (between the financial and real market) the capital market can provide long term funding (roll over debts) and central bank interest rate can affect the whole structure of interest rates, i.e., the 
rate of discount impacts the long term rate that determines the long term rate of interest and investment. These arguments are based on the assumptions that market mechanisms are not efficient since the economy structurally is unable to operate at levels of full employment; i.e., prices are not correct and that money impacts economic activity (is nonneutral). Thereby, a wide scope of government policies to counteract private spending decisions, are proposed; along with fiscal deficit policies. The QTM is also dismissed arguing that money is tied up in financial instruments (capital markets).

In the second version of capital market operations is argue that its effect are double edge. Capitalist financial complex institutions can issue liquidity independently of investment decisions, moving away from the argument of financial intermediation; and the long-term rate of interest, characterized as a monetary variable, is the variable that affects most investment spending. Thereby, monetary policy can be extremely effective by lengthening short term into long term debts (rolling over debts) so long speculation doesn't dominate financial capital decisions.

Post Keynesian analysis of capital market split into two different views. On the light of Keynes 1930s writings is argued that central bank can smooth the securities yield return, deep capital markets can be functional for economic growth in providing liquidity to illiquid assets, lengthen the debt structure and cope with currency mismatches. The opposite is that view capital markets only raises financial returns and modify the concentration of income. Independently of these two views was it is import to bear in mind that monetary policy by its own cannot revert downwards cycle or recessions and active policy can be helpful to acquire liquidity.

\section{ACKNOWLEDGEMENT}

This paper was written as part of the research project PAPIIT IN-303314.

\section{REFERENCES}

Bellofiore Riccardo and Pierro Ferri. 2001. "Things fall apart, the center cannot hold. Introduction, Pp. 1-30 in Financial Keynesianism and Market Instability The Economic Legacy of Hyman Minsky, Volume 1, The economic Legacy of Hyman Minsky, edited by R. Bellofiore and P. Fierro, Cheltenham, UK • Northampton, MA, USA, Edward Elgar.

Bellofiore, Ricccardo and Mario Seccareccia. 1999. "Monetary Circuit" Pp. 753-56. In Encyclopedia of Political Economy, Volume 2 Economic Policy, edited by P.A. O'Hara, London: Routledge
Caldwell Bruce. 1996. "Introduccion" in Obras de Friedrich A. Hayek, Volumen IX. Contra Keynes y Cambridge. Ensayos y Correspondencia, edited by Bruce Cadwell, Unión Editorial, Colombia.

Hayek, Friedrich A. 1931. Prices and Production, Augusts M. Kelley, Publishers, New York

Hayek, Friedrich A. 1933 Monetary Theory and the Trade Cycle, Alden Press

Graziani, Augusto A. 2003 The monetary theory production, Cambridge, United Kindgom: Cambridge University Press

Kaldor, Nicholas. 1970 "The New Monetarism”, accessed November, 2014 http://public.econ.duke.edu/ kdh9/Courses/Graduate\%20Ma cro\%20History/Readings-1/Kaldor.pdf

Kalecki M [939](1954) "The determinants of investment", reprinted in Selected Essays on the Dynamics of the capitalist economy, 1933-1970", Cambridge, United Kingdom: Cambridge University Press, 1971, pp. 110-123.

Keynes, John M. [1930](1935). A Treatise on Money, Book 1 The pure theory of Money, London, United Kingdom, Macmillan and Co, Limited.

Keynes, J.M. [1930](1935). "A Treatise on Money, Book 2, The applied theory of money, London, United Kingdom, Macmillan and Co, Limited.

Keynes, John M. 1936. The General Theory of Employment, Interest, and Money, Harvest/Harcourt, Inc. 1964.

Keynes John, M. 1937. "Alternative theories of the rate of interest", The Economic Journal, 47(186) (June), pp. 241-252, http://www.jstor.org/stable/2225525 Accessed: 13/07/2010

Keynes, John M. 1937b. "The 'ex ante' theory of the rate of interest", The Economic Journal, 47(188): 663-669, http://www.jstor.org/stable/2225323 Accessed: 13/07/2010

Le-Bourva John. 1992. "Money creation and credit multipliers", Review of Political Economy, 4(4): 447-446. http://dx.doi.org/10.1080/09538259200000029

Lenin, Vladimir. [1916](1963). "Imperialism, the Highest Stage of Capitalism" in Lenin's Selected Works, Volume 1, Moscow, Soviet Union, Progress Publishers, 1963, Moscow.

Minsky, Hyman. 1964. "Financial Crises, Financial System, and the Performance of the Economy" Pp. 173-380 in Private Capital Markets, Research Study Two, New York, United States, Prentice Hall, Inc, Englewood Cliffs.

Minsky, Hyman. 1975. John Maynard Keynes, New York, United States, Macmillan.

Minsky, Hyman.1986. Stabilizing an Unstable Economy, New York, Twenty Century Fund.

Minsky, Hyman. 1991. "The Endogeneity of Money" Pp. 207-220, in Nickolas Kaldor and Mainstream Economics, E. Nell \& W. Semmler, editors, St. Martin's Press.

Michell, Jo and Jan Toporowski. 2013-2014 "Critical Observations on financialization and the financial process", International Journal of Political economy, 42 (4), Winter, pp. 67-82.

Moore, Basil. 1988. Horizontalists and Verticalists: The Macroeconomics of Credit Money", Cambridge, United Kingdom, Press

Parguez, Alain and Mario Seccareccia. 2000. "The Credit Theory of Money: the Monetary Circuit Approach". Pp- 101-123 in in What is Money? J, Smithin editor, Routledge, Canada and the USA.

Rochon Louis P. 1999. Credit, Money and Production. An alternative Post-Keynesian Approach, Edward Elgar, Cheltemham UK.

Rochon, Louis P. 2006. "Endogenous Money, Central Banks and the Banking System: Basil Moore and the Supply of Credits" Pp. 170-186, in Complexity, Endogenous Money and Macroeconomic Theory, Essays in Honour of Basil J. Moore, M. Setterfield, editor, Cheltenham, UK. Edward Elgar. 
Toporowski, Jan. 2000. The end of finance, capital market inflation, financial derivatives and pension fund capitalism, Routledge Frontiers of Political Economy
Toporowski, Jan. 2014. Créditos y Crisis: Desde Marx a Minsky, forthcoming, Mexico, Porrua editors.

Received on 01-09-2015

Accepted on 07-09-2015

Published on 14-12-2015

DOI: http://dx.doi.org/10.6000/1929-7092.2015.04.20

(C) 2015 Noemi Levy Orlik; Licensee Lifescience Global.

This is an open access article licensed under the terms of the Creative Commons Attribution Non-Commercial License (http://creativecommons.org/licenses/by-nc/3.0/) which permits unrestricted, non-commercial use, distribution and reproduction in any medium, provided the work is properly cited. 